\title{
Enantiomeric Ratio Changes of Terpenes in Essential Oils from Hybrid Eucalyptus grandis $\times$ E. tereticornis and its Pure Species
}

\author{
Cecilia Naspi, Agustín A. Costa, Alejandro Lucia, Paola G. Audino and \\ Hector M. Masuh*
}

Centro de Investigaciones de Plagas e Insecticidas (UNIDEF/CONICET), Juan Bautista de La Salle 4397 (B1603ALO) Villa Martelli, Buenos Aires, Argentina

\begin{abstract}
Some Eucalyptus species produce oils with biological activities and the effect of their interspecific hybridization on the enantiomeric composition of terpenes has not been reported. The enantiomeric excesses of monoterpenes in the essential oil of Eucalyptus grandis $\times$ E. tereticornis and its parental taxa were determined by gas chromatography-mass spectrometry (GC-MS), and to resolve coelutions problems by preparative high performance liquid chromatography (HPLC) and GC-MS with two columns in series. The essential oil composition of the hybrid presented qualitative and quantitative differences with the composition of its parental taxa. Great differences were found for the enantiomeric ratio in monoterpene alcohols among the three essential oils. Our results suggest that the enantiomeric analysis can be a reliable method for the study of how the interspecific hybridization can module the enantiomeric chemical profile in Eucalyptus essential oils. These results suggest the use of interspecific hybridization to improve or expand the source of bioactive compounds.
\end{abstract}

Keywords: essential oils, enantiomers, Eucalyptus hybrid

\section{Introduction}

The genus Eucalyptus (Myrtaceae) is native to Australia, comprises about 800 species and is now one of the most widely cultivated plants in the world due to many favorable characteristics such as high growth rates and wide adaptability to soils and climate. ${ }^{1}$ Most of Eucalyptus species produce oils, some with biological activities of great importance for pest control, but few of them are being exploited for commercial uses. ${ }^{1,2}$ In forest plantations, hybrid breeding is gaining more interest as a potential tool to improve tree performance, growth rate, propagation, pulp yield and resistance to pests and diseases. ${ }^{3}$ Even though the essential oils from Eucalyptus have been widely studied in different species including hybrids there is a lack of information about the enantiomers proportions. ${ }^{3-8}$

The analysis of enantiomers is an issue of interest in the study of natural products, flavors, pharmacology and organic chemistry. It is well known that both enantiomers of a same molecule may have different biological activities mainly due to differences at the molecular recognition by a protein receptor. ${ }^{9}$ Terpene enantiomers can differ in the way

*e-mail: hmasuh@gmail.com they are perceived as odorants, not only because of their characteristic aromatic notes but also due to their different odor threshold. ${ }^{10}$ The analysis of enantiomers in an essential oil can be useful to determine their authenticity in those cases in which one of its components is present in a high enantiomeric purity, or exists in a specific enantiomeric ratio. ${ }^{11,12}$ Moreover, the determination of chiral compounds can be used for defining chemotypes in aromatic plants and for establishing their geographical origin. ${ }^{13}$ In addition to this, the enantiomeric ratio of terpenes can vary depending on the part of the plant in study. ${ }^{14}$

Many different chiral stationary phases based on permethylated cyclodextrins have been reported for their capability to solve different enantiomeric pairs in plant volatiles and essential oils. . $^{2,13,15,16}$

Due to the complexity of the composition of some essential oils and the similarity in chemical structure of their components, some terpenes usually coelute in gas chromatography (GC). To solve this problem, high performance liquid chromatography (HPLC) may be a useful alternative as a pre-fractionation technique. In fact, essential oil characterization by HPLC analysis has previously been reported based on both direct and reverse phase chromatography and UV, fluorescence, diode array 
and mass spectrometric detection. ${ }^{17-19}$ In consequence, a semi-preparative separation by HPLC for its later analysis by gas chromatography could be suitable for terpene characterization in essential oils..$^{20,21}$

The objective of this work was to use this combination of techniques to determine the enantiomeric composition for the main chiral monoterpenes in the essential oil of the hybrid Eucalyptus grandis $\times$ E. tereticornis and its relationship with E. tereticornis Smith and E. grandis W. Hill ex Maiden. The effect of the interspecific hybridization on the enantiomeric composition of terpenes has not been reported up to the present.

\section{Experimental}

\section{Plant material}

Eucalyptus grandis W. Hill ex Maiden, Eucalyptus tereticornis Smith and the hybrid Eucalyptus grandis $\times$ E. tereticornis were used for this study. The plant samples were obtained from an experimental field located at $34^{\circ} 33^{\prime}$ 42" S, 58 30' 39" W (Centro de Investigaciones de Plagas e Insecticidas (CIPEIN), Villa Martelli, Buenos Aires, Argentina). The experimental field was built by two months old seedlings. The Eucalyptus species were acquired in Forest Nurseries, registered at INASE-SENASA (National Seeds Institute of the Republic of Argentina-National Service of Agriculture Sanity and Quality). E. tereticornis, $E$. grandis and the hybrid $E$. grandis $\times$ E. tereticornis were purchased at Paul Forestal, Forest Nursery (No. INASE J/5188, San Isidro, Buenos Aires Argentina).

\section{Essential oil extraction}

Fresh leaves (two years old) were submitted to steam distillation in our lab using a modified Clevenger-type apparatus. The extraction was performed for $70 \mathrm{~min}$, time at which the yield remained constant. ${ }^{4}$ Five independent extractions, consisting of a mixture of nine individuals, were performed for each Eucalyptus species. After extraction, the essential oil was separated from water and dried over anhydrous sodium sulfate. The five extractions were pooled to obtain one sample per species. The essential oils were maintained under $-4{ }^{\circ} \mathrm{C}$ in argon atmosphere until use.

\section{Chemical standards}

All chemical standards were purchased from Sigma-Aldrich ${ }^{\circledR}$ Argentina: $(S)-(-)-\alpha$-pinene (98\%), $(R)-(+)$ - $\alpha$-pinene $(98 \%),(R)-(+)$-camphene $(80 \%)$,
$(S)$-(-)-camphene $(80 \%),(S)-(-)-\beta$-pinene $(98 \%)$, $(R)-(+)-\beta$-pinene $(98 \%), \alpha$-terpinene $(85 \%), p$-cymene $(99 \%),(S)-(-)$-limonene $(96 \%),(R)-(+)$-limonene (97\%), 1,8-cineole (99\%), $\gamma$-terpinene $(97 \%)$, linalool (97\%), (S)-(-)-borneol (90\%), (S)-(+)-4-terpineol (96\%), $\alpha$-terpineol (99\%), caryophyllene oxide (99\%).

\section{Essential oils chemical composition}

It was combined the gas and high performance liquid chromatography (GC and HPLC) to determine and quantify the chemical composition of the essential oils of the Eucalyptus species (Figure 1). The first step was to analyze the composition of essential oils by GC using two columns, DB-5 and DB-WAX, and two detectors, mass spectrometry (MS) and flame ionization detector (FID) (Figure 1a, Essential oil composition by gas chromatography-mass spectrometry analysis section). To solve the enantiomers, it was used the GC with a chiral column, CycloSil- $\beta$, and the detectors mentioned above (Figure 1b, Enantiomeric analysis of Eucalyptus essential oils section). Preparative HPLC was performed to solve problems of coelution of certain molecules (Figure 1c, Fractionation of the essential oil by high performance liquid chromatography section). Finally, the fractions obtained with preparative HPLC were analyzed by GC using a non-polar column, DB-5MS, and two columns in tandem, DB-WAX + CycloSil- $\beta$ and an MS as detector (Figures 1d and 1e, HPLC fraction analysis by GC-MS section).

Essential oil composition by gas chromatography-mass spectrometry analysis

The essential oils were analyzed in a Shimadzu GC-17A gas chromatograph interfaced to a Shimadzu quadrupole mass spectrometer (GCMS-QP5050A), and equipped with a DB-5MS column (J\&W Scientific, Agilent Technologies, $30 \mathrm{~m} \times 0.25 \mathrm{~mm}$ i.d., $0.25 \mu \mathrm{m}$ film thickness). The GC conditions were programmed as follows: injector and detector temperature were 250 and $260{ }^{\circ} \mathrm{C}$, respectively. Initial oven temperature was held at $60{ }^{\circ} \mathrm{C}$ for $3 \mathrm{~min}$, then increased to $100{ }^{\circ} \mathrm{C}\left(2{ }^{\circ} \mathrm{C} \mathrm{min}^{-1}\right)$ and finally up to $240{ }^{\circ} \mathrm{C}\left(7^{\circ} \mathrm{C} \mathrm{min}^{-1}\right)$ with a final hold time of 3 min. Helium (99.995\%) was used as carrier gas at a flow rate of $1.6 \mathrm{~mL} \mathrm{~min}{ }^{-1}$ (constant column pressure of $100 \mathrm{kPa}$ ). The essential oil samples were diluted in hexane $\left(1 \mathrm{mg} \mathrm{mL}^{-1}\right)$, and $0.3 \mu \mathrm{L}$ were injected with a split ratio of 1:30. The essential oils solutions were also analyzed in GC-MS with a polar DB-WAX column (J\&W Scientific, Agilent Technologies, $30 \mathrm{~m} \times 0.32 \mathrm{~mm}$ i.d. $\times 0.25 \mu \mathrm{m}$ film thickness). The temperature ramp started at $40{ }^{\circ} \mathrm{C}(3 \mathrm{~min}$ hold time) and then increased up to a final temperature of 


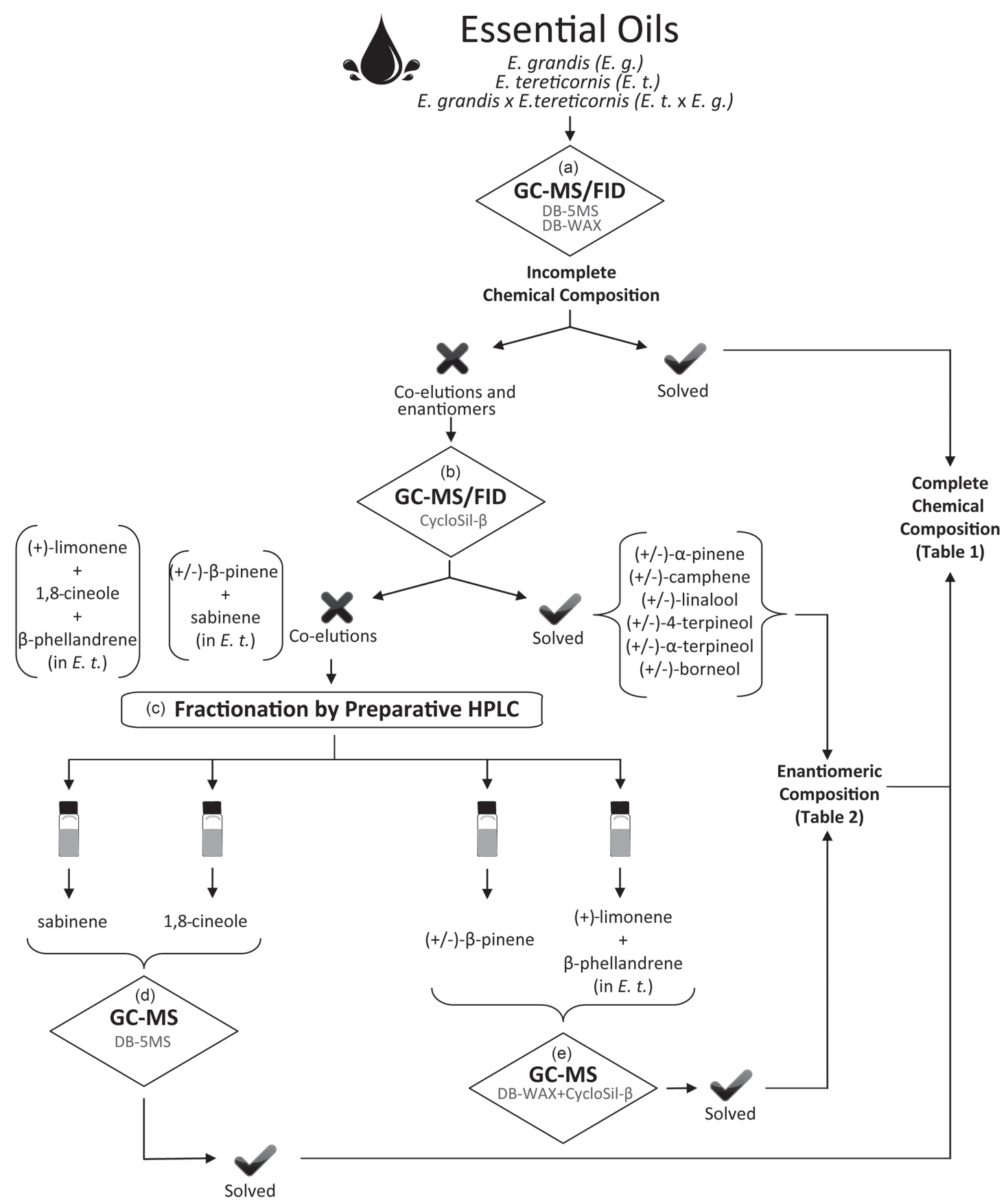

Figure 1. Representative diagram of techniques and methodologies used to separate pure compounds and enantiomers and finally, to determine the proportion of the (+) and (-) enantiomers in the Eucalyptus essential oils. (a) Essential oil composition by gas chromatography-mass spectrometry analysis section; (b) Enantiomeric analysis of Eucalyptus essential oils section; (c) Fractionation of the essential oil by high performance liquid chromatography section; (d, e) HPLC fraction analysis by GC-MS section.

$200^{\circ} \mathrm{C}\left(3^{\circ} \mathrm{C} \mathrm{min}^{-1}\right)$ with a final hold time of $3 \mathrm{~min}$. Column inlet pressure was set up at $35 \mathrm{kPa}\left(53.6 \mathrm{~cm} \mathrm{~s}^{-1}\right.$ linear velocity), flow column was $2.2 \mathrm{~mL} \mathrm{~min}^{-1}$ with a split ratio of 1:10 (injection volume: $0.5 \mu \mathrm{L}$ ). Injector and detector were set at 240 and $245^{\circ} \mathrm{C}$, respectively.

The mass spectra were recorded between 45 and $350 \mathrm{amu}$, with ionization energy of $70 \mathrm{eV}$. Quantification with FID was performed using normalized relative peaks areas obtained from the GC chromatograms. Individual components were identified by different methods: (i) mass spectra obtained from each compound were compared against Wiley mass spectral database ver. 7 and NIST database; (ii) comparison of retention times with those of authentic compounds (Sigma-Aldrich ${ }^{\circledR}$ ); (iii) comparison of linear retention indexes obtained by co-injection of authentic compounds with a homologous series of 
$n$-alkanes $\left(\mathrm{C}_{9}-\mathrm{C}_{17}\right.$, Sigma-Aldrich) in DB-5MS, with those reported in bibliography; (iv) comparison of linear retention indexes obtained in DB-WAX column with those available in bibliography. ${ }^{22-26}$ Quantitation analyses were performed on a Shimadzu GC-2014 with a flame ionization detector and using a DB-WAX column (J\&W Scientific, Agilent Technologies, $30 \mathrm{~m} \times 0.32 \mathrm{~mm}$ i.d., $0.25 \mu \mathrm{m}$ film thickness). Nitrogen was used as carrier gas. The column pressure and flow, temperature program, injector and detector temperatures were equal as GC-MS analysis with DB-WAX column. The analysis for each essential oil was performed in triplicate.

\section{Enantiomeric analysis of Eucalyptus essential oils}

The essential oils were analyzed in a Shimadzu GC-17A gas chromatograph interfaced with a Shimadzu quadrupole mass spectrometer (GCMS-QP5050A). The chiral column used was CycloSil- $\beta$ that consists of $30 \%$ heptakis (2,3-di-O-methyl-6- $O$ - $t$-butyl dimethylsilyl)$\beta$-cyclodextrin in DB-1701 as stationary phase (J\&W Scientific, Agilent Technologies, $30 \mathrm{~m} \times 0.25 \mathrm{~mm}$ i.d., film thikness $0.25 \mu \mathrm{m})$. The GC column was initially programmed at $70{ }^{\circ} \mathrm{C}$ (isothermal for $5 \mathrm{~min}$ ), then up to $83{ }^{\circ} \mathrm{C}\left(2{ }^{\circ} \mathrm{C} \mathrm{min}^{-1}\right)$, immediately up to $85^{\circ} \mathrm{C}\left(0.5^{\circ} \mathrm{C} \mathrm{min}^{-1}\right)$ and finally up to $200^{\circ} \mathrm{C}\left(5^{\circ} \mathrm{C} \mathrm{min}^{-1}\right)$ with a final hold time of $5 \mathrm{~min}$. The carrier gas was helium $(99.995 \%)$ using a split ratio of 1:30, a constant pressure of $100 \mathrm{kPa}$, a linear velocity of $45.6 \mathrm{~cm} \mathrm{~s}^{-1}$ and flow rate of $1.5 \mathrm{~mL} \mathrm{~min}^{-1}$. The samples were diluted in hexane $\left(1 \mathrm{mg} \mathrm{mL}^{-1}\right)$ and $0.5 \mu \mathrm{L}$ were injected. The injector and detector temperatures were 235 and $240{ }^{\circ} \mathrm{C}$, respectively. The ionization energy was $70 \mathrm{eV}$, and mass scan was performed between 45 and $280 \mathrm{amu}$. For the identification of individual components, retention times were compared with those of authentic compounds and their mass spectra were analyzed using database libraries (Wiley mass spectral database version 7; NIST database). The elution order of each enantiomeric pair was assigned by comparison of retention time with those of authentic standards and confirmed with previous reports. ${ }^{13,16,27}$ Linear retention indexes were obtained by co-injection of authentic standards with a homologous series of $n$-alkanes in GC-MS using a different temperature ramp $\left(70{ }^{\circ} \mathrm{C}, 5 \mathrm{~min}\right.$ isothermal; $3{ }^{\circ} \mathrm{C} \mathrm{min}^{-1}$ up to $200{ }^{\circ} \mathrm{C}$ hold time $5 \mathrm{~min}$ ) with the other chromatographic conditions having the same value as described before.

Enantiomeric excesses (ee) were calculated from peak areas obtained from GC-FID analyses with a Shimadzu GC-2014 chromatograph using nitrogen as carrier gas, $100 \mathrm{kPa}$ column pressure, $32.1 \mathrm{~cm} \mathrm{~s}^{-1}$ linear velocity and $1.28 \mathrm{~mL} \mathrm{~min}^{-1}$ of column flow. The oven temperature program was identical as described before. The enantiomeric excess is expressed as percentage, i.e., [(predominant enantiomer - minor enantiomer)/ (predominant enantiomer + minor enantiomer) $] \times 100$.

Fractionation of the essential oil by high performance liquid chromatography

Analytical conditions for HPLC analysis of essential oils

Chemical analysis was performed in a Shimadzu high performance liquid chromatograph consisting of two pumps LC-8A (A and B), an FCV-130AL reservoir selection valve, an SIL-10AF autosampler, a CBM-20A communication bus module, an SPD-M20A photodiode array detector and an FRC-10A fraction collector. An analytical reverse phase column was used (GraceSmart RP 18, $250 \times 4.6 \mathrm{~mm}$ i.d., $5 \mu \mathrm{m}$ particle size) at a constant flow rate of $0.8 \mathrm{~mL} \mathrm{~min}^{-1}$. HPLC analysis was performed with different gradients of acetonitrile (pump A, ACN) and water (pump B): initially a linear gradient from 30 to $50 \%$ of ACN (23 min), then an isocratic step ( $2 \mathrm{~min}$ ), then a linear gradient from 50 to $60 \%$ of ACN (25 min) and finally a linear gradient from 60 to $80 \%$ of ACN (20 min). After each analysis, the column was equilibrated to the initial conditions for $10 \mathrm{~min}$ with a linear gradient back to the initial conditions: $\mathrm{ACN}: \mathrm{H}_{2} \mathrm{O}$ (30:70). Essential oils samples were diluted in isopropanol $\left(2 \mathrm{mg} \mathrm{mL}^{-1}\right)$ and $5 \mu \mathrm{L}$ were injected. The chromatogram was acquired using a photodiode array detector (wavelength $190-800 \mathrm{~nm})$ at room temperature $\left(25^{\circ} \mathrm{C}\right)$ using a slit width of $1.2 \mathrm{~nm}$ and band width of $1 \mathrm{~nm}$. UV spectra obtained for each peak were compared with reported data. ${ }^{19}$ All proceedings and chromatograms analyses were performed with LC Solution Software (version 1.23, Shimadzu Corporation, Japan).

Semi-preparative fractionation of the essential oil by HPLC

Chromatographic conditions and solvent gradient were the same as in the analytical analyses. The essential oil samples were diluted in isopropanol $\left(100 \mathrm{mg} \mathrm{mL}^{-1}\right)$ and $5 \mu \mathrm{L}$ were injected. The HPLC chromatograph was programmed on the basis of slope $\left(\mu \mathrm{V} \mathrm{s}^{-1}\right)$ and level $(\mu \mathrm{V})$ to collect each peak in a different vial. The semipreparative chromatographic procedure was performed five times; each fraction corresponding to the same peak was collected together in a same vial. The fractions were extracted once with $0.2 \mathrm{~mL}$ of hexane; the organic layers were dried under anhydrous sodium sulfate and stored at $-4{ }^{\circ} \mathrm{C}$ until their analysis. The assignment of each peak identity was based on the comparison of the retention times with authentic standards when available and by the analysis of each fraction obtained from HPLC by GC-MS. 
Maximum absorption wavelengths were also corroborated with reported data (Tables 1-3). ${ }^{19}$

\section{HPLC fraction analysis by GC-MS}

HPLC fraction analysis by GC-MS with non-polar column

The organic extracts obtained after organic partition of HPLC fractions were analyzed by GC-MS. Chromatographic conditions were similar as described for essential oils analyses: $1.5 \mu \mathrm{L}$ of each organic fraction were injected in DB-5MS column, using the same temperature ramp program described before, with a split ratio of $1: 2$ instead. The components in each fraction were identified by: (i) comparison of mass spectra against database (Wiley mass spectral database ver. 7, NIST database); (ii) comparison of linear retention indexes, using a homologous series of $n$-alkanes $\left(\mathrm{C}_{9}-\mathrm{C}_{17}\right.$, Aldrich) with those of bibliography. ${ }^{22-24}$

\section{HPLC fraction analysis with chiral GC-MS}

The enantiomeric analysis of limonene in E. grandis was performed on fraction 14 obtained from the HPLC fractionation. Analytical conditions were similar as described in Enantiomeric analysis of Eucalyptus

Table 1. Composition of HPLC fractions from E. grandis

\begin{tabular}{|c|c|c|c|c|c|c|}
\hline HPLC fraction & $\begin{array}{l}\text { Retention } \\
\text { time / min }\end{array}$ & $\begin{array}{c}\text { Method of } \\
\text { identification }\end{array}$ & $\lambda \max / \mathrm{nm}$ & Compound assignment & $\mathrm{LRI}^{\mathrm{b}}$ & $\begin{array}{l}\text { Percentage in } \\
\text { fraction } / \%\end{array}$ \\
\hline 1 & 15.28 & n.i. & - & n.i. & - & - \\
\hline 2 & 15.87 & $\mathrm{~B}, \mathrm{D}$ & $<200$ & trans-carveol & 1220 & 67.0 \\
\hline 3 & 17.54 & $\mathrm{~B}, \mathrm{D}$ & $<200$ & trans-pinocarveol & 1130 & 89.6 \\
\hline \multirow[t]{3}{*}{4} & 18.16 & $\mathrm{~B}, \mathrm{D}$ & $<200$ & trans-pinocarveol & 1130 & 3.8 \\
\hline & & A,B,C,D & & borneol & 1167 & 7.7 \\
\hline & & A,B,C,D & & $\alpha$-terpineol & 1192 & 88.5 \\
\hline \multirow[t]{3}{*}{5} & 19.31 & A,B,C,D & $<200,225(\mathrm{sh}), 255$ & borneol & 1167 & 36.1 \\
\hline & & A,B,C,D & & 4-terpineol & 1176 & 24.6 \\
\hline & & A,B,C,D & & $\alpha$-terpineol & 1192 & 39.4 \\
\hline \multirow[t]{5}{*}{6} & 21.02 & A,B,C,D & $<200,239,271$ & 1,8-cineole & 1029 & 10.2 \\
\hline & & A,B,C,D & & linalool & 1101 & 46.4 \\
\hline & & A,B,C,D & & borneol & 1167 & 11.2 \\
\hline & & $\mathrm{A}, \mathrm{B}, \mathrm{C}, \mathrm{D}$ & & 4-terpineol & 1176 & 5.1 \\
\hline & & A,B,C,D & & $\alpha$-terpineol & 1192 & 3.7 \\
\hline \multirow[t]{2}{*}{7} & 21.72 & A,B,C,D & $<200,242$ & 1,8-cineole & 1029 & 19.7 \\
\hline & & $\mathrm{B}, \mathrm{D}$ & & fenchol & 1116 & 59.9 \\
\hline \multirow[t]{2}{*}{8} & 22.23 & A,B,C,D & $<200,244(\mathrm{sh}), 275$ & 1,8 -cineole & 1029 & 73.7 \\
\hline & & $\mathrm{B}, \mathrm{D}$ & & fenchol & 1116 & 21.6 \\
\hline \multirow[t]{3}{*}{9} & 22.75 & A,B,C,D & $<200,256(\mathrm{sh}), 278$ & 1,8-cineole & 1029 & 64.5 \\
\hline & & $\mathrm{B}, \mathrm{D}$ & & fenchol & 1116 & 20.6 \\
\hline & & A,B,C,D & & timol & 1286 & 10.1 \\
\hline 10 & 23.52 & - & - & n.i. & - & - \\
\hline 11 & 37.95 & $\mathrm{~B}, \mathrm{D}$ & $<200$ & spathulenol & 1580 & 44.7 \\
\hline 12 & 42.85 & A,B,C,D & $<200,213(\mathrm{sh}), 265$ & $p$-cymene & 1021 & 98.5 \\
\hline 13 & 54.57 & A,B,C,D & $<200$ & $\gamma$-terpinene & 1054 & 99.0 \\
\hline \multirow[t]{3}{*}{14} & 55.38 & A,B,C,D & $<200$ & camphene & 944 & 7.3 \\
\hline & & $\mathrm{A}, \mathrm{B}, \mathrm{C}, \mathrm{D}$ & & limonene & 1025 & 62.3 \\
\hline & & $\mathrm{A}, \mathrm{B}, \mathrm{C}, \mathrm{D}$ & & $\gamma$-terpinene & 1054 & 30.4 \\
\hline 15 & 56.85 & A & $<200$ & $\beta$-pinene & - & - \\
\hline 16 & 61.9 & $\mathrm{~A}, \mathrm{~B}, \mathrm{C}, \mathrm{D}$ & $<200$ & $\alpha$-pinene & 929 & 95.3 \\
\hline
\end{tabular}

n.i.: not identified; sh: shoulder. ${ }^{2}$ Method of identification: A: comparison with authentic standard in HPLC; B: comparison of MS spectrum against spectral databases (Wiley-Nist-Adams); C: retention time and LRI comparison with authentic standard in GC-MS analysis; D: LRI comparison with DB-5MS column bibiliographic data; ${ }^{b} \mathrm{LRI}$ : linear retention index on DB-5MS. 
Table 2. Composition of HPLC fractions from E. tereticornis

\begin{tabular}{|c|c|c|c|c|c|c|}
\hline HPLC peak & $\begin{array}{l}\text { Retention } \\
\text { time / min }\end{array}$ & $\begin{array}{c}\text { Method of } \\
\text { identification }\end{array}$ & $\lambda \max / \mathrm{nm}$ & Compound assignment & $\mathrm{LRI}^{\mathrm{b}}$ & $\begin{array}{c}\text { Percentage in } \\
\text { fraction } / \%\end{array}$ \\
\hline 1 & 15.25 & $\mathrm{~B}, \mathrm{D}$ & $<200,215,209(\mathrm{sh})$ & cuminol & 1291 & 80.5 \\
\hline 2 & 16.08 & $\mathrm{~B}, \mathrm{D}$ & $200(\mathrm{sh}), 230$ & cryptone & 1182 & 85.5 \\
\hline \multirow[t]{2}{*}{3} & 18.19 & $\mathrm{~B}, \mathrm{D}$ & $<200$ & cryptone & 1182 & 3.9 \\
\hline & & $\mathrm{A}, \mathrm{B}, \mathrm{C}, \mathrm{D}$ & & $\alpha$-terpineol & 1192 & 89.5 \\
\hline \multirow[t]{2}{*}{4} & 18.83 & $\mathrm{~B}, \mathrm{D}$ & $<200,211(\mathrm{sh}), 240$ & trans-p-menth-2-en-1-ol & 1139 & 57.0 \\
\hline & & A,B,C,D & & $\alpha$-terpineol & 1192 & 29.1 \\
\hline 5 & 19.32 & $\mathrm{~A}, \mathrm{~B}, \mathrm{C}, \mathrm{D}$ & $<200$ & 4-terpineol & 1176 & 99.0 \\
\hline \multirow[t]{3}{*}{6} & 21.13 & $\mathrm{~A}, \mathrm{~B}, \mathrm{C}, \mathrm{D}$ & $<200$ & linalool & 1101 & 46.3 \\
\hline & & $\mathrm{B}, \mathrm{D}$ & & $c i s-p$-menth-2-en-1-ol & 1121 & 5.4 \\
\hline & & A,B,C,D & & 4-terpineol & 1176 & 30.7 \\
\hline 7 & 21.63 & $\mathrm{~A}, \mathrm{~B}, \mathrm{C}, \mathrm{D}$ & $<200$ & linalool & 1101 & 99.0 \\
\hline 8 & 22.64 & A,B,C,D & $<200$ & 1,8-cineole & 1029 & 79.7 \\
\hline 9 & 24.59 & B,D & $200,225(\mathrm{sh}), 259$ & cuminaldehyde & 1243 & 98.6 \\
\hline \multirow[t]{2}{*}{10} & 36.38 & $\mathrm{~B}, \mathrm{D}$ & $<200$ & spathulenol & 1580 & 8.0 \\
\hline & & $\mathrm{B}, \mathrm{D}$ & & isospathulenol & 1634 & 69.4 \\
\hline 11 & 37.84 & $\mathrm{~B}, \mathrm{D}$ & $<200$ & spathulenol & 1580 & 96.8 \\
\hline 12 & 42.75 & A,B,C,D & $<200,213(\mathrm{sh}), 265$ & $p$-cymene & 1021 & 86.4 \\
\hline 13 & 45.58 & $\mathrm{~A}, \mathrm{~B}, \mathrm{C}, \mathrm{D}$ & $<200,243(\mathrm{sh}), 277$ & caryophyllene oxide & 1585 & 85.9 \\
\hline 14 & 50.23 & B,D & $<200$ & sabinene & 968 & 99.5 \\
\hline 15 & 51.60 & $\mathrm{~B}, \mathrm{D}$ & $<200,207$ (sh), 223 & $\beta$-myrcene & 987 & 92.2 \\
\hline \multirow[t]{4}{*}{16} & 53.86 & $\mathrm{~B}, \mathrm{D}$ & $<200,245(\mathrm{sh}), 266$ & $\beta$-myrcene & 987 & 16.2 \\
\hline & & $\mathrm{A}, \mathrm{B}, \mathrm{C}, \mathrm{D}$ & & $\alpha$-terpinene & 1013 & 31.9 \\
\hline & & $\mathrm{A}, \mathrm{B}, \mathrm{C}, \mathrm{D}$ & & $\gamma$-terpinene & 1054 & 10.3 \\
\hline & & - & & n.i. & - & 41.5 \\
\hline \multirow[t]{2}{*}{17} & 54.61 & $\mathrm{~B}, \mathrm{D}$ & $199(\mathrm{sh}), 230$ & $\beta$-phellandrene & 1026 & 93.7 \\
\hline & & $\mathrm{A}, \mathrm{B}, \mathrm{C}, \mathrm{D}$ & & $\gamma$-terpinene & 1054 & 6.3 \\
\hline \multirow[t]{3}{*}{18} & 55.19 & $\mathrm{~B}, \mathrm{D}$ & $<200,219(\mathrm{sh}), 235$ & $\alpha$-phellandrene & 1005 & 27.2 \\
\hline & & $\mathrm{A}, \mathrm{B}, \mathrm{C}, \mathrm{D}$ & $249(\mathrm{sh}), 263$ & limonene & 1025 & 15.1 \\
\hline & & $\mathrm{B}, \mathrm{D}$ & & $\beta$-phellandrene & 1026 & 57.7 \\
\hline \multirow[t]{4}{*}{19} & 56.78 & $\mathrm{~B}, \mathrm{D}$ & $<200$ & $\alpha$-tujene & 922 & 13.2 \\
\hline & & A,B,C,D & & $\beta$-pinene & 973 & 0.4 \\
\hline & & $\mathrm{A}, \mathrm{B}, \mathrm{C}, \mathrm{D}$ & & $\alpha$-phellandrene & 1005 & 14.6 \\
\hline & & $\mathrm{A}, \mathrm{B}, \mathrm{C}, \mathrm{D}$ & & $\beta$-phellandrene & 1026 & 52.8 \\
\hline 20 & 61.58 & $\mathrm{~A}, \mathrm{~B}, \mathrm{C}, \mathrm{D}$ & $<200$ & $\alpha$-pinene & 929 & 99.3 \\
\hline
\end{tabular}

n.i.: not identified; sh: shoulder. ${ }^{2}$ Method of identification: A: comparison with authentic standard in HPLC; B: comparison of MS spectrum against spectral databases (Wiley-Nist-Adams); C: retention time and LRI comparison with authentic standard in GC-MS analysis; D: LRI comparison with DB-5MS column bibliographic data; ${ }^{b}$ LRI: linear retention index on DB-5MS.

essential oils section, using a split ratio of 1:2 instead. The enantiomeric excesses for limonene and $\beta$-pinene for E. tereticornis and the hybrid were calculated using a chromatographic system consisting of two columns connected in series. This system consisted of a gas chromatograph (Shimadzu, GCMS-QP5050A) equipped with a DB-WAX column (column 1, J\&W Scientific,
Agilent Technologies, $30 \mathrm{~m} \times 0.32 \mathrm{~mm}$ i.d. $\times 0.25 \mu \mathrm{m}$ film thickness) connected in series to a CycloSil- $\beta$ (column 2, J\&W Scientific, Agilent Technologies, $30 \mathrm{~m} \times 0.25 \mathrm{~mm}$ i.d., film thickness $0.25 \mu \mathrm{m}$ ) using a column connector (Hewlett-Packard 5041-2174 pk/10). The injector and interface temperatures were set at 240 and $245^{\circ} \mathrm{C}$, respectively. The carrier gas was helium $(99.995 \%)$, 
Table 3. Composition of HPLC fractions from E. grandis $\times$ E. tereticornis

\begin{tabular}{|c|c|c|c|c|c|c|}
\hline HPLC peak & $\begin{array}{l}\text { Retention } \\
\text { time / min }\end{array}$ & $\begin{array}{c}\text { Method of } \\
\text { identification }\end{array}$ & $\lambda \max / \mathrm{nm}$ & Compound assignment & $\mathrm{LRI}^{\mathrm{b}}$ & $\begin{array}{l}\text { Percentage in } \\
\text { fraction } / \%\end{array}$ \\
\hline \multirow[t]{2}{*}{1} & 15.95 & $\mathrm{~B}, \mathrm{D}$ & $<200$ & trans-carveol & 1220 & 40.4 \\
\hline & & - & & n.i. & - & 26.9 \\
\hline 2 & 17.59 & $\mathrm{~B}, \mathrm{D}$ & $<200$ & trans-pinocarveol & 1130 & 89.6 \\
\hline \multirow[t]{3}{*}{3} & 18.22 & $\mathrm{~B}, \mathrm{D}$ & $<200$ & trans-pinocarveol & 1130 & 11.1 \\
\hline & & $\mathrm{A}, \mathrm{B}, \mathrm{C}, \mathrm{D}$ & & borneol & 1167 & 3.9 \\
\hline & & $\mathrm{A}, \mathrm{B}, \mathrm{C}, \mathrm{D}$ & & $\alpha$-terpineol & 1192 & 84.0 \\
\hline \multirow[t]{4}{*}{4} & 19.36 & $\mathrm{~B}, \mathrm{D}$ & $<200$ & trans-pinocarveol & 1130 & 2.9 \\
\hline & & $\mathrm{A}, \mathrm{B}, \mathrm{C}, \mathrm{D}$ & & borneol & 1167 & 27.9 \\
\hline & & $\mathrm{A}, \mathrm{B}, \mathrm{C}, \mathrm{D}$ & & 4-terpineol & 1176 & 40.7 \\
\hline & & $\mathrm{A}, \mathrm{B}, \mathrm{C}, \mathrm{D}$ & & $\alpha$-terpineol & 1192 & 28.6 \\
\hline \multirow[t]{4}{*}{5} & 21.52 & $\mathrm{~A}, \mathrm{~B}, \mathrm{C}, \mathrm{D}$ & $<200$ & 1,8 -cineole & 1029 & 98.0 \\
\hline & & $\mathrm{A}, \mathrm{B}, \mathrm{C}, \mathrm{D}$ & & linalool & 1101 & 0.3 \\
\hline & & $\mathrm{A}, \mathrm{B}, \mathrm{C}, \mathrm{D}$ & & fenchol & 1116 & 1.2 \\
\hline & & $\mathrm{A}, \mathrm{B}, \mathrm{C}, \mathrm{D}$ & & $\alpha$-terpineol & 1192 & 0.1 \\
\hline 6 & 42.32 & $\mathrm{~A}, \mathrm{~B}, \mathrm{C}, \mathrm{D}$ & $<200,213$ (sh), 266 & p-cymene & 1021 & 98.5 \\
\hline 7 & 51.18 & - & - & n.i. & - & - \\
\hline 8 & 54.78 & $\mathrm{~A}, \mathrm{~B}, \mathrm{C}, \mathrm{D}$ & $<200$ & limonene & 1025 & 70.8 \\
\hline \multirow[t]{2}{*}{9} & 55.54 & $\mathrm{~A}, \mathrm{~B}, \mathrm{C}, \mathrm{D}$ & $<200$ & limonene & 1025 & 40.5 \\
\hline & & $\mathrm{A}, \mathrm{B}, \mathrm{C}, \mathrm{D}$ & & $\beta$-pinene & 973 & 49.5 \\
\hline 10 & 61.42 & $\mathrm{~A}, \mathrm{~B}, \mathrm{C}, \mathrm{D}$ & $<200$ & $\alpha$-pinene & 929 & 99.3 \\
\hline
\end{tabular}

n.i.: not identified; sh: shoulder. ${ }^{a}$ Method of identification: A: comparison with authentic standard in HPLC; B: comparison of MS spectrum against spectral databases (Wiley-Nist-Adams); C: retention time and LRI comparison with authentic standard in GC-MS analysis; D: LRI comparison with DB-5MS column with those of bibliographic data; bRI: linear retention index on DB-5MS.

using a constant column pressure of $100 \mathrm{kPa}$, column flow $0.8 \mathrm{~mL} \mathrm{~min}^{-1}$ (linear velocity $23.2 \mathrm{~cm} \mathrm{~s}^{-1}$ ). The fractions were analyzed using a $1: 2$ split ratio and $1.5 \mu \mathrm{L}$ of injection volume. Column oven was initially programmed at $60{ }^{\circ} \mathrm{C}$ (isothermal for $5 \mathrm{~min})$, increased at $220^{\circ} \mathrm{C}\left(3{ }^{\circ} \mathrm{C} \mathrm{min}^{-1}\right)$ with $3 \mathrm{~min}$ of final hold time. Chemical assignments were done by comparison of the retention times with available standards and by mass spectrum comparison against database libraries ${ }^{22}$ (Wiley mass spectral database ver. 7 , NIST database). Limonene enantiomers were analyzed in fraction 18 and $\beta$-pinene in fraction 19 in E. tereticornis; meanwhile, in $E$. grandis $\times E$. tereticornis, limonene was analyzed in fraction 11 . To improve detection, the lectures of signals were performed in SIM (selected-ion monitoring) mode with $m / z 68$ for limonene (base peak $\mathrm{C}_{5} \mathrm{H}_{8}{ }^{+}$) and $m / z, 93$ for $\beta$-pinene (base peak, $\mathrm{C}_{7} \mathrm{H}_{9}{ }^{+}$).

\section{Results and Discussion}

Initially, we analyzed the chemical composition of Eucalyptus essential oils by GC-MS/FID with two columns (DB-5MS and DB-WAX). The analysis by GC-MS/FID allowed the identification of most of the terpenes in the essential oil, showing that the main components were monoterpenes (Table 4).

In Eucalyptus grandis, monoterpene hydrocarbons $(68.40 \%)$ constituted the main components of the essential oil; the most abundant was $\alpha$-pinene (48.89\%), followed by $p$-cymene $(10.82 \%)$ and limonene $(4.08 \%)$. Oxygenated monoterpenes $(24.64 \%)$ were also present, including 1,8-cineole (12.90\%), $\alpha$-terpineol (4.96\%) and borneol $(2.03 \%)$. A low quantity of the sesquiterpene spathulenol was found in this essential oil. These results are in concordance with those reported previously. ${ }^{4,28}$

The essential oil of E. tereticornis is characterized by the presence of monoterpene hydrocarbons $(55.24 \%)$, oxygenated monoterpenes $(28.34 \%)$ and a small amount of oxygenated sesquiterpenes $(8.36 \%)$. The most abundant terpenes were 1,8-cineole (13.30\%), $p$-cymene (15.78\%) and $\beta$-phellandrene $(18.28 \%)$. Previous reports of E. tereticornis composition informed similar proportion of 1,8-cineole, but higher quantities of $\alpha$-pinene. ${ }^{29,30}$ Besides, some essential oils with low quantity of 1,8-cineole were also reported. ${ }^{7,31}$ This discrepancy in the chemical 
Table 4. Chemical composition of Eucalyptus essential oils analyzed by gas chromatography

\begin{tabular}{|c|c|c|c|c|c|c|c|}
\hline \multirow{2}{*}{ No. } & \multirow{2}{*}{ Compound } & \multicolumn{2}{|c|}{ LRI } & \multirow{2}{*}{$\begin{array}{c}\text { Method of } \\
\text { identification }\end{array}$} & \multicolumn{3}{|c|}{ Area $^{\mathrm{d}} / \%$} \\
\hline & & DB-5MS ${ }^{\mathrm{a}}$ & DB-WAX ${ }^{b}$ & & EGr & $\mathrm{ETe}$ & EGrETe \\
\hline 1 & $\alpha$-thujene & 922 & 1016 & $\mathrm{~A}, \mathrm{C}$ & - & 1.78 & - \\
\hline 2 & $\alpha$-pinene & 929 & 1012 & $\mathrm{~A}, \mathrm{~B}, \mathrm{C}$ & 48.89 & 6.46 & 25.71 \\
\hline 3 & camphene & 944 & 1047 & $\mathrm{~A}, \mathrm{~B}, \mathrm{C}$ & 0.61 & - & 0.21 \\
\hline 4 & sabinene & 968 & 1108 & $\mathrm{~A}, \mathrm{C}$ & - & 1.06 & - \\
\hline 5 & $\beta$-pinene & 973 & 1091 & $\mathrm{~A}, \mathrm{~B}, \mathrm{C}$ & 0.41 & 0.43 & 2.28 \\
\hline 7 & $\beta$-myrcene & 987 & 1153 & $\mathrm{~A}, \mathrm{C}$ & - & 0.98 & - \\
\hline 8 & $\alpha$-phellandrene & 1005 & 1147 & $\mathrm{~A}, \mathrm{C}$ & - & 6.45 & - \\
\hline 9 & $\alpha$-terpinene & 1013 & 1163 & $\mathrm{~A}, \mathrm{~B}, \mathrm{C}$ & - & 0.38 & - \\
\hline 10 & $p$-cymene & 1021 & 1250 & $\mathrm{~A}, \mathrm{~B}, \mathrm{C}$ & 10.82 & 15.78 & 0.53 \\
\hline 11 & limonene & 1025 & 1184 & $\mathrm{~A}, \mathrm{~B}, \mathrm{C}$ & 4.08 & 2.22 & 4.60 \\
\hline 12 & $\beta$-phellandrene & 1026 & 1190 & $\mathrm{~A}, \mathrm{C}$ & - & 18.28 & - \\
\hline 13 & 1,8 -cineole & 1029 & 1193 & $\mathrm{~A}, \mathrm{~B}, \mathrm{C}$ & 12.90 & 13.30 & 58.17 \\
\hline 14 & $\gamma$-terpinene & 1054 & 1230 & $\mathrm{~A}, \mathrm{~B}, \mathrm{C}$ & 3.59 & 1.42 & - \\
\hline 15 & linalool & 1101 & 1548 & $\mathrm{~A}, \mathrm{~B}, \mathrm{C}$ & 0.25 & 0.80 & - \\
\hline 16 & fenchol & 1116 & 1572 & $\mathrm{~A}, \mathrm{C}$ & 1.04 & - & - \\
\hline 17 & $c i s$ - $p$-menth-2-en-1-ol & 1121 & 1552 & $\mathrm{~A}, \mathrm{C}$ & - & 0.80 & - \\
\hline 18 & campholenaldehyde & 1123 & 1465 & $\mathrm{~A}, \mathrm{C}$ & 0.90 & - & - \\
\hline 19 & trans-pinocarveol & 1136 & 1637 & $\mathrm{~A}, \mathrm{C}$ & 1.33 & - & 0.65 \\
\hline 20 & trans-p-menth-2-en-1-ol & 1139 & 1617 & $\mathrm{~A}, \mathrm{C}$ & - & 0.51 & - \\
\hline 21 & borneol & 1167 & 1685 & $\mathrm{~A}, \mathrm{~B}, \mathrm{C}$ & 2.03 & - & 0.36 \\
\hline 22 & 4-terpineol & 1176 & 1589 & $\mathrm{~A}, \mathrm{~B}, \mathrm{C}$ & 0.34 & 4.22 & 0.21 \\
\hline 23 & cryptone & 1182 & 1635 & $\mathrm{~A}, \mathrm{C}$ & - & 4.48 & - \\
\hline 24 & $\alpha$-terpineol & 1192 & 1686 & $\mathrm{~A}, \mathrm{~B}, \mathrm{C}$ & 4.96 & 1.41 & 1.71 \\
\hline 25 & cuminaldehyde & 1243 & 1749 & $\mathrm{~A}, \mathrm{C}$ & - & 1.27 & - \\
\hline 26 & phellandranal & 1278 & 1685 & $\mathrm{~A}, \mathrm{C}$ & - & 0.44 & - \\
\hline 27 & spathulenol & 1580 & 2105 & $\mathrm{~A}, \mathrm{C}$ & $<0.1$ & 7.07 & - \\
\hline 28 & caryophyllene oxide & 1585 & 1944 & $\mathrm{~A}, \mathrm{~B}, \mathrm{C}$ & - & 0.78 & - \\
\hline 29 & isospathulenol & 1634 & 2207 & $\mathrm{~A}, \mathrm{C}$ & - & 0.51 & - \\
\hline \multicolumn{2}{|c|}{ Monoterpene hydrocarbon } & & & & 68.40 & 55.24 & 33.33 \\
\hline \multicolumn{2}{|c|}{ Oxygenated monoterpene } & & & & 23.75 & 27.23 & 61.10 \\
\hline \multicolumn{2}{|c|}{ Sesquiterpene hydrocarbon } & & & & - & - & - \\
\hline \multicolumn{2}{|c|}{ Oxygenated sesquiterpene } & & & & 0.1 & 8.36 & - \\
\hline Total & & & & & 92.25 & 90.83 & 94.43 \\
\hline
\end{tabular}

LRI: linear retention index in ${ }^{a} \mathrm{DB}-5 \mathrm{MS}$; ${ }^{\mathrm{D}} \mathrm{DB}-\mathrm{WAX}$; ${ }^{\mathrm{c}}$ method of identification: A: mass spectrum comparison against library (NIST-Wiley-Adams); B: comparison of retention time and LRI with authentic standard; C: LRI comparison with those of bibliography; ${ }^{\mathrm{d}}$ relative percentage of total area in the chromatogram. EGr: Eucalyptus grandis; ETe: Eucalyptus tereticornis; EGrETe: Eucalyptus grandis $\times$ E. tereticornis.

composition could be attributed to the existence of different chemotypes influenced by climate conditions. The monoterpene hydrocarbon $\beta$-phellandrene was present in higher concentration than previously reported., ${ }^{4,30,32} \mathrm{In}$ this essential oil, some oxygenated sesquiterpenes were also found: spathulenol (7.07\%) was the most abundant and has previously been found in E. tereticornis. ${ }^{7,32}$ Some minor components, such as limonene, cryptone, 4-terpineol, $\alpha$-terpineol and cuminaldehyde are commonly found in this essential oil. ${ }^{4}$

The analysis of the essential oil of the hybrid E. grandis $\times E$. tereticornis showed an enrichment in the oxygenated monoterpene, 1,8 -cineole $(58.17 \%)$ compared to the parents composition. This enrichment, as 
consequence of interspecific hybridization, was previously found in other studies. ${ }^{4,28}$ Limonene (4.60\%) was found in a similar proportion than in $E$. grandis; meanwhile, $\beta$-pinene $(2.28 \%)$ was more abundant respect to the pure species in accordance with results previously reported. ${ }^{5}$ The $\alpha$-pinene $(25.71 \%)$ is present in an intermediate concentration with respect to the parental composition. The hybridization resulted in a lack of sesquiterpenes and there was not novel biosynthesis of terpenes in the hybrid in accordance to literature. ${ }^{8,33}$

In addition to this initial analysis, we analyzed the enantiomeric composition of some monoterpenes by using GC-MS/FID with a CycloSil- $\beta$ capillary column (Enantiomeric analysis of Eucalyptus essential oils section). As a result, eight enantiomeric pairs of monoterpenes were determined: $\alpha$-pinene, camphene, $\beta$-pinene, limonene, linalool, 4-terpineol, borneol and $\alpha$-terpineol based on their presence in at least two of the essential oils. The order of elution for each enantiomer was assigned by comparison with authentic standards and is in concordance with those reported in bibliography using equivalent stationary phases. ${ }^{9,12,13,16}$ The elution orders of (+) and (-) enantiomers of linalool and $\alpha$-terpineol were obtained from previous reports with equivalent column (Table 5)..$^{9,13}$

At this moment, we were able to determine the enantiomeric excess of six enantiomeric pairs: $\alpha$-pinene, camphene, linalool, 4-terpineol, borneol and $\alpha$-terpineol. However, $\beta$-pinene and limonene still coeluted with other components, thus interfering with their resolution (Figure 1). In these cases, when the samples are complex, it is common to observe coelution of two or more pure or enantiomeric components, resulting in an overlap of signal peaks observed in the total ion chromatogram. For example, $(i)$ in the analysis of E. tereticornis essential oil, the retention time of $(+)-\beta$-pinene coincided with sabinene (unknown enantiomer), while $(+)$-limonene coeluted with $\beta$-phellandrene and 1,8-cineole. (ii) In E. grandis $\times E$. tereticornis high peak areas of 1,8-cineole also overlapped the signal of (+)-limonene (Figure 1c).

To solve these coelutions of components we used the pre-fractionation by HPLC and these fractions generated were characterized by GC-MS with a DB-5MS column or two columns in a series (DB-WAX + CycloSil- $\beta$ ). In the last case, DB-WAX column was connected to the injector port and the CycloSil- $\beta$ column was connected to the detector.

As a result of HPLC analysis in reverse phase, the monoterpene alcohols eluted first, followed by sesquiterpene alcohols and finally monoterpene hydrocarbons. Despite this, $p$-cymene, an aromatic oxygenated monoterpene, eluted after spathulenol but prior to caryophyllene oxide, both oxygenated sesquiterpenes. Cryptone was the only ketone terpene found, present only in E. tereticornis, and

Table 5. Enantiomeric excess and predominant enantiomer of chiral monoterpenes in Eucalyptus essential oils using CycloSil- $\beta$ column in GC-FID

\begin{tabular}{|c|c|c|c|c|}
\hline \multirow{2}{*}{ Enantiomeric compound } & \multirow{2}{*}{ LRI } & \multicolumn{3}{|c|}{ Enantiomeric excess (predominant enantiomer) ${ }^{\mathrm{a}} / \%$} \\
\hline & & E. grandis & E. tereticornis & E. grandis $\times$ E. tereticornis \\
\hline$(S)-(-)$ - $\alpha$-Pinene & 977 & $89.03(+)$ & $47.21(+)$ & $84.81(+)$ \\
\hline$(R)-(+)-\alpha$-Pinene & 980 & & & \\
\hline$(S)$-(-)-Camphene & 1010 & $74.30(+)$ & b & $43.27(+)$ \\
\hline$(R)-(+)$-Camphene & 1015 & & & \\
\hline$(R)-(+)-\beta$-Pinene & 1025 & $34.72(-)$ & $50.18(-)^{\mathrm{a}}$ & $83.84(-)$ \\
\hline$(S)-(-)-\beta$-Pinene & 1031 & & & \\
\hline$(S)$-(-)-Limonene & 1059 & $61.48(+)$ & $29.15(+)^{\mathrm{a}}$ & $5.10(+)^{\mathrm{a}}$ \\
\hline$(R)-(+)$-Limonene & 1075 & & & \\
\hline$(R)$-(-)-Linalool & 1219 & $75.06(+)$ & $82.13(+)$ & b \\
\hline$(S)$-(+)-Linalool & 1226 & & & \\
\hline$(S)-(+)-4-T e r p i n e o l$ & 1301 & $64.53(+)$ & $82.57(-)$ & $11.2(-)$ \\
\hline$(R)-(-)-4$-Terpineol & 1308 & & & \\
\hline$(S)$-(-)-Borneol & 1344 & $88.56(+)$ & b & $20.6(-)$ \\
\hline$(R)-(+)$-Borneol & 1348 & & & \\
\hline$(S)-(-)-\alpha$-Terpineol & 1352 & $66.10(+)$ & $31.08(+)$ & $7.20(-)$ \\
\hline$(R)-(+)$ - $\alpha$-Terpineol & 1362 & & & \\
\hline
\end{tabular}

a Enantiomeric excess calculated by prefractionation with HPLC and analysis with double column system (DB-WAX+CycloSil- $\beta$ ); ${ }^{\mathrm{b}}$ means not present in the essential oil. LRI: Linear retention index relative to an homologous series of $n$-alkanes; enantiomeric excess is expressed as percentage and predominant enantiomer and showed in parenthesis. 
eluted in second place after the aromatic alcohol cuminol. As it is observed in the HPLC traces, many peaks were partially resolved not only for monoterpene alcohols but also for monoterpenic hydrocarbons (Tables 1-3). Many monoterpene hydrocarbons have such a similar structure that they are not properly resolved even in an analytical run. Our results showed the coelution of limonene with camphene and $\alpha$-phellandrene. These findings have also been reported in reverse phase HPLC. ${ }^{19}$

In the fractionation of Eucalyptus tereticornis oil by HPLC, 1,8-cineole was separated from $\beta$-phellandrene and limonene, and sabinene was separated from $\beta$-pinene. These compounds, 1,8-cineole and sabinene, were determined by GC-MS with the DB-5MS column (HPLC fraction analysis by GC-MS with non-polar column section). The HPLC fractions of the E. tereticornis essential oil containing limonene (which coelutes with $\beta$-phellandrene) and $\beta$-pinene were used for the chiral analysis with the DB-WAX + CycloSil- $\beta$ columns (HPLC fraction analysis with chiral GC-MS section). In this case,
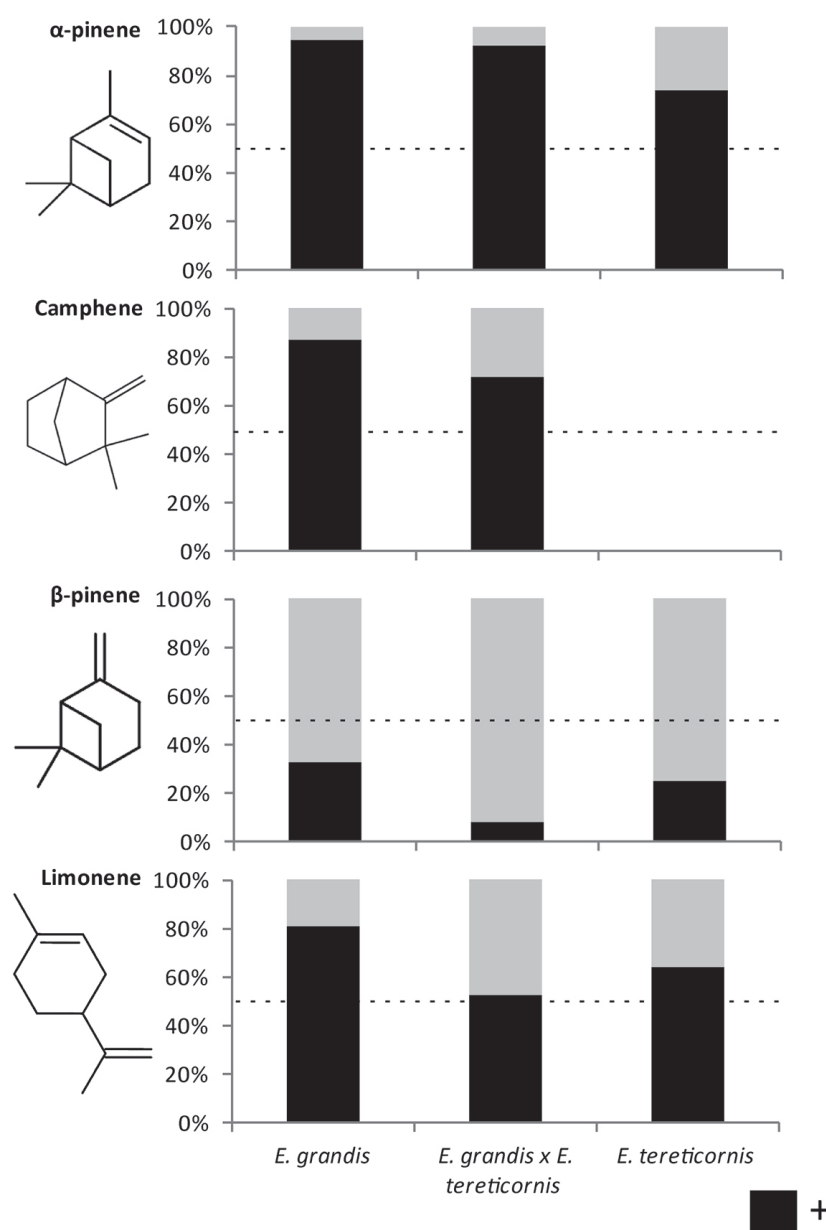

the first column (DB-WAX) could separate limonene (KI $1184)$ versus $\beta$-phellandrene (KI 1190). The enantiomeric excess of limonene in E. grandis and E. grandis $\times$ E. tereticornis was calculated through the analyses of the fraction obtained by HPLC with the columns in a series, too (Table 5).

Furthermore, the components of Eucalyptus essential oils were present in their both enantiomeric forms, and their proportion is very important as their bioactivity may be different. Figure 2 shows the proportion of enantiomers for each component determined. In all the compounds evaluated both enantiomers (+) and (-) were found. Linalool, camphene and borneol were not present in at least one of three species analyzed. The proportion of $(+)$ and $(-)$ enantiomers of $\alpha$-pinene, $\beta$-pinene and limonene was similar among E. grandis, E tereticornis and the hybrid. On the other hand, the proportion of the enantiomers of 4-terpineol and $\alpha$-terpineol from the $E$. grandis $\times E$. tereticornis was intermediate between the proportions found in its parentals.
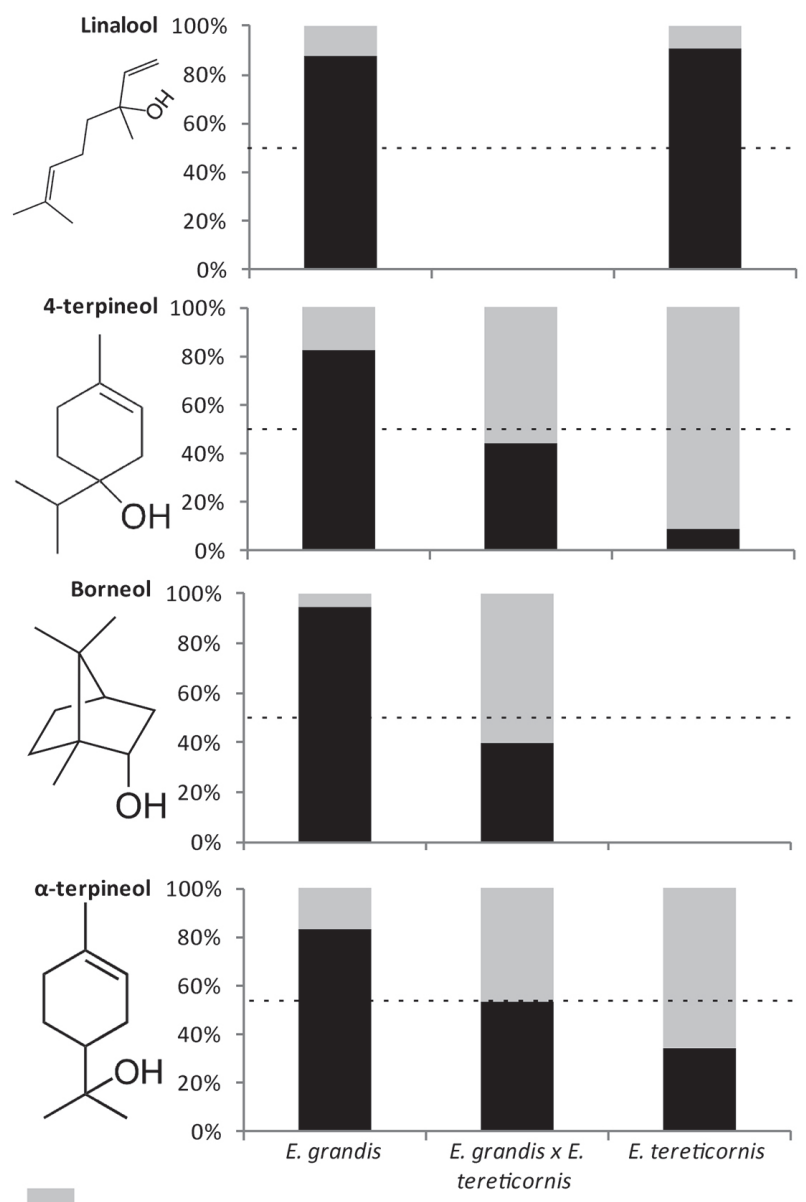

Figure 2. Percentage of each enantiomer $(+)$ and (-) for each component in its respective essential oil (E. grandis, E. tereticornis and E. grandis $\times$ E. tereticornis). The total amount of each component $((+)$ and $(-)$ enantiomer $)$ in the essential oil was considered $100 \%((+)+(-)=100 \%)$. The grey bar shows the proportion of $(-)$ enantiomer and the black bar the $(+)$ enantiomer. 


\section{Conclusions}

This paper provides an exhaust chemical composition analysis of the essential oils of Eucalyptus grandis, E. tereticornis and the hybrid. Combined methodologies like preparative HPLC and GC with columns in a series were useful to resolve coelution problems. The essential oil composition of the hybrid presented qualitative and quantitative differences with the composition of its parental taxa. Furthermore, differences in the enantiomeric proportions of optically active components were also observed.

Finally, our results suggest that the enantiomeric analysis of terpenes can be a reliable method to study how the interspecific hybridization can module the chemical profile in Eucalyptus essential oils as potential sources of bioactive compounds.

\section{Acknowledgments}

This investigation was financially supported by Agencia Nacional de Promoción Científica y Tecnológica (ANPCyT, Argentina) PICT 0797-2008.

\section{References}

1. Brooker, I. In Eucalyptus: The Genus Eucalyptus (Medicinal and Aromatic Plants - Industrial Profiles); Coppen, J. J. W., ed.; Taylor \& Francis Inc.; London, UK, 2002, ch. 1.1.

2. Batish, D. R.; Singh, H. P.; Kohli, R. K.; Kaur, S.; For. Ecol. Manage. 2008, 256, 2166.

3. Varshney, V. K.; Pandey, A.; Thoss, V.; Kumar, A.; Ginwal, H. S.; Ann. For. Res. 2011, 55, 53.

4. Lucia, A.; Licastro, S.; Zerba, E.; Masuh, H.; Entomol. Exp. Appl. 2008, 129, 107.

5. Baptista, E. B.; Zimmermann-Franco, D. C.; Lataliza, A. A. B.; Raposo, N. R. B.; Rev. Soc. Bras. Med. Trop. 2015, 48, 746.

6. Elaissi, A.; Medini, H.; Khouja, M. L.; Simmonds, M.; Lynen, F.; Farhat, F.; Chemli, R.; Harzallah-Skhiri, F.; Chem. Biodiversity 2011, 8, 352.

7. Dellacassa, E.; Menéndez, P.; Moyna, P.; Soler, E.; Flavour Fragrance J. 1990, 5, 91.

8. Farah, A.; Fechtal, M.; Chaouch, A.; Biotechnol., Agron., Soc. Environ. 2002, 6, 163.

9. Tkachev, A. V.; Russ. Chem. Rev. 2007, 76, 951.

10. Ravid, U. In Selected Topics in the Chemistry of Natural Products; Ikan, R., ed.; World Scientific Publishing: Singapore, 2008, ch. 6.

11. Bicchi, C. D.; Amato, A.; Rubiolo, P.; J. Chromatogr. A 1999, $843,99$.
12. Ruiz del Castillo, M. L.; Blanch, G. P.; Herraiz, M.; J. Chromatogr. A 2004, 10, 87.

13. Bisht, D.; Chanotiya, C. S.; Rana, M.; Semwal, M.; Ind. Crops Prod. 2009, 30, 422.

14. Borg-Karlson, A. K.; Lindström, M.; Norin, T.; Persson, M.; Valterová, I.; Acta Chem. Scand. 1993, 47, 138.

15. König, W. A.; Gehrcke, B.; Icheln, D.; Evers, P.; Dönnecke, J.; Wang, W.; J. High Resolut. Chromatogr. 1992, 15, 367.

16. Pragadheesh, V. S.; Yadav, A.; Singh, M.; Chanotiya, C. S.; Nat. Prod. Commun. 2013, 8, 221.

17. Ross, M. S. F.; J. Chromatogr. A 1978, 160, 199.

18. Newbery, J. E.; Lopez de Haddad, M. P.; Charlwood, K. A.; Anal. Chim. Acta 1983, 147, 387.

19. Turek, C.; Stintzing, F. C.; Anal. Bioanal. Chem. 2011, 400, 3109.

20. Chamblee, T. S.; Clark Jr., B. C.; Radford, T.; Iacobucci, G. A.; J. Chromatogr. A 1985, 330, 141.

21. Buiarelli, F.; Cartoni, G. P.; Coccioli, F.; Leone, T.; J. Chromatogr. A 1996, 730, 9.

22. Adams, R. P.; Identification of Essential Oil Components by Gas Chromatography/Mass Spectrometry, $4^{\text {th }}$ ed.; Allured Publishing Corporation: Carol Stream, Illinois, USA, 2007.

23. Kim, T. H.; Lee, S. M.; Kim, Y. S.; Kim, K. H.; Oh, S.; Lee, H. J.; Food Chem. 2003, 83, 151.

24. Asuming, W. A.; Beauchamp, P. S.; Descalzo, J. T.; Dev, B. C.; Dev, V.; Frost, S.; Ma, C. W.; Biochem. Syst. Ecol. 2005, 33, 17.

25. Goodner, K. L.; LWT - Food Sci. Technol. 2008, 41, 951.

26. Lee, S. J.; Umano, K.; Shibamoto, T.; Lee, K. G.; Food Chem. 2005, 91, 131.

27. Liberto, E.; Cagliero, C.; Sgorbini, B.; Bicchi, C.; Sciarrone, D.; Zellner, B. D.; Mondello, L.; Rubiolo, P.; J. Chromatogr. A 2008, 1195, 117.

28. Lucia, A.; Gonzalez Audino, P.; Seccacini, E.; Licastro, S.; Zerba, E.; Masuh, H.; J. Am. Mosq. Control Assoc. 2007, 23, 299.

29. Batista-Pereira, L. G.; Fernandes, J. B.; Corrêa, A. G.; Silva, M. F. G. F.; Vieira, P. C.; J. Braz. Chem. Soc. 2006, 17, 555.

30. Kaur, S.; Singh, H. P.; Batish, D. R.; Kohli, R. K.; J. Med. Plants Res. 2011, 5, 4788.

31. Ogunwande, I. A.; Olawore, N. O.; Adeleke, K. A.; Konig, W. A.; J. Essent. Oil Res. 2003, 15, 297.

32. Pino, J. A.; Marbot, R.; Quert, R.; García, H.; Flavour Fragrance J. 2002, 17, 1.

33. Farah, A.; Fechtal, M.; Chaouch, A.; Ann. For. Sci. 2002, 59, 445 .

Submitted: May 7, 2017

Published online: August 31, 2017 